\title{
Tinjauan Yuridis Filosofis Eksistensi Kearifan Lokal
}

\author{
Zainul Akmal
}

Fakultas Hukum, Universitas Riau, Indonesia

zainulakmal@leturer.unri.a.id

Abstract

This study aims to determine the relationship between local wisdom and indigenous peoples and the dependence of local wisdom on its creators at the level of application. It was found that local wisdom is partly produced by indigenous peoples and partly produced by non-indigenous people. Local wisdom is also not carried out in its application with its creator, because local wisdom and universal values can be transformed or inherited or learned by anyone, so that it can be applied by anyone.

Keywords: Existence; local wisdom; indingeous people

\section{Pendahuluan}

Tulisan ini bertujuan untuk mengetahui hubungan "Kearifan Lokal" dengan Masyarakat Adat". Kajian ini bisa memberikan pencerahan bagi siapa saja, terutama para hakim dalam menegakkan hukum dan keadilan. Sekarang ini sebagian penegakan hukum berkeyakinan, bahwa penerapan kearifan lokal oleh para petani dipandang melanggar hukum. ${ }^{1}$ Akibat anggapan tersebut menciderai rasa keadilan di dalam masyarakat. ${ }^{2}$

Indonesia mengatur tentang "Kearifan lokal" dalam beberapa peraturan perundang-undangan. Pengaturan terkait kearifan lokal dalam suatu Undang-Undang (UU), ditafsirkan dalam peraturan yang lebih rendah bahwa hanya masyarakat adat (masyarakat hukum adat) yang bisa menjadi pelaku pelaksana kearifan lokal. Implikasi dari peraturan yang lebih rendah ini membuat tidak semua orang bisa melaksanakan kearifan lokal. Sudut pandang pemerintah

\footnotetext{
${ }^{1}$ Engki Prima Putra, 'Divonis Bersalah 6 Bulan, 15 Hari Terdakwa Irwan Pembakar Lahan Langsung Bebas', RiauPos.Co, p. Https://riaupos.jawapos.com/rokanhulu/19/08/2020/.

${ }^{2}$ Rambe Endar, 'AMPR Geruduk Mapolda Riau, Tuntut Keadilan Petani Rohul Iwan Kini Menjalani Sidang Kasus Pembakaran Lahan', Detikperistiwa.Com, 2020, p. https://www.detikperistiwa.com/news183255/ampr-ge.
}

yang membuat kebijakan menjadikan pemilik dan penerapan kearifan lokal bersifat eksklusif. Kearifan lokal hanya bisa diterapkan oleh masyarakat tertentu yang sudah ditetapkan oleh peraturan perundang-undangan.

Pengaturan kearifan lokal bisa dilihat dibeberapa UU diantaranya, UndangUndang Nomor 1 Tahun 2014 tentang Perubahan atas Undang-Undang Nomor 27 Tahun 2007 tentang Pengelolaan Wilayah Pesisir dan Pulau-Pulau Kecil (Perubahan UU PWPPPK) ${ }^{3}$, UndangUndang Nomor 32 Tahun 2009 tentang Perlindungan dan Pengelolaan Lingkungan Hidup (UU PPLH) ${ }^{4}$, dan Undang-Undang Nomor 11 Tahun 2020 Tentang Cipta Kerja (UU CK) ${ }^{5}$.

Peraturan pelaksana atau aturan yang lebih rendah dibentuk oleh pemerintah pusat dan pemerintah daerah terkait pelaku pelaksanaan kearifan lokal bisa dilihat pada peraturan diantaranya, Peraturan Menteri Negara Lingkungan

\footnotetext{
${ }^{3}$ Undang-Undang Republik Indonesia Nomor 1 Tahun 2014 Tentang Perubahan Atas Undang Undang Nomor 27 Tahun 2007 Tentang Pengelolaan Wilayah Pesisir Dan Pulau-Pulau Kecil.

${ }^{4}$ Undang-Undang Republik Indonesia Nomor 32 Tahun 2009 Tentang Perlindungan Dan

Pengelolaan Lingkungan Hidup.

${ }^{5}$ Undang Undang Republik Indonesia Nomor 11 Tahun 2020 Tentang Cipta Kerja.
} 
Hidup Nomor 10 Tahun 2010 Tentang Mekanisme Pencegahan Pencemaran Dan/Atau Kerusakan Lingkungan Hidup Yang Berkaitan Dengan Kebakaran Hutan Dan/Atau Lahan (Permen LH 10/2010) ${ }^{6}$, dan Peraturan Daerah Provinsi Kalimantan Tengah Nomor 1 Tahun 2020 Tentang Pengendalian Kebakaran Lahan (Perda PKL) ${ }^{7}$.

Melihat realitas sosial, sebagian orang berfikir bahwa kearifan lokal hanya dimiliki oleh mndang-undangan.

Pengaturan kearifan lokal bisa dilihat dibeberapa UU diantaranya, UndangUndang Nomor 1 Tahun 2014 tentang Perubahan atas Undang-Undang Nomor 27 Tahun 2007 tentang Pengelolaan Wilayah Pesisir dan Pulau-Pulau Kecil (Perubahan UU PWPPPK) ${ }^{8}$, UndangUndang Nomor 32 Tahun 2009 tentang Perlindungan dan Pengelolaan Lingkungan Hidup (UU PPLH) ${ }^{9}$, dan Undang-Undang Nomor 11 Tahun 2020 Tentang Cipta Kerja (UU CK) ${ }^{10}$.

Peraturan pelaksana atau aturan yang lebih rendah dibentuk oleh pemerintah pusat dan pemerintah daerah terkait pelaku pelaksanaan kearifan lokal bisa dilihat pada peraturan diantaranya, Peraturan Menteri Negara Lingkungan Hidup Nomor 10 Tahun 2010 Tentang Mekanisme Pencegahan Pencemaran Dan/Atau Kerusakan Lingkungan Hidup Yang Berkaitan Dengan Kebakaran Hutan Dan/Atau Lahan (Permen LH 10/2010) ${ }^{11}$, dan Peraturan Daerah Provinsi Kalimantan Tengah Nomor 1 Tahun 2020

\footnotetext{
${ }^{6}$ Peraturan Menteri Negara Lingkungan Hidup Nomor 10 Tahun 2010 Tentan Mekanisme Pencegahan Pencemaran Dan/Atau Kerusakan Lingkungan Hidup Yang Berkaitan Dengan Kebakaran Hutan Dan/Atau Lahan <www.hukumonline.com>.

${ }^{7}$ Peraturan Daerah Provinsi Kalimantan Tengah Nomor 1 Tahun 2020 Tentang Pengendalian Kebakaran Lahan.

${ }^{8}$ Undang-Undang Republik Indonesia Nomor 1 Tahun 2014 Tentang Perubahan Atas Undang Undang Nomor 27 Tahun 2007 Tentang Pengelolaan Wilayah Pesisir Dan Pulau-Pulau Kecil.
}

Tentang Pengendalian Kebakaran Lahan (Perda PKL) $^{12}$.

Melihat realitas sosial, sebagian orang berfikir bahwa kearifan lokal hanya dimiliki oleh masyarakat tertentu yaitu masyarakat adat. Masyarakat yang tidak termasuk dalam kategori masyarakat adat dianggap tidak memiliki kearifan lokal. Sebagian meyakini bahwa setiap masyarakat memiliki kearifan lokal, walaupun tidak dikategorikan sebagai masyarakat adat.

Sebagian meyakini bahwa kearifan lokal hanya bisa diterapkan oleh masyarakat adat, sedangkan selain dari masyarakat adat tidak bisa menerapkan kearifan lokal. Sebagian meyakini bahwa yang bisa menerapkan kearifan lokal hanya masyarakat tempatan. Masyarakat yang sudah turun temurun bertempat tinggal dan hidup di daerah tersebut, yang juga dikenal dengan suku asli termasuk masyarakat adat. Jika seseorang adalah suku pendatang di daerah tersebut, maka orang tersebut tidak bisa menerapkan kearifan lokal.

Sebagiannya lagi berpendapat bahwa setiap orang bisa menerapkan kearifan lokal dalam kehidupan sehari-harinya. Walaupun orang tersebut bukan masyarakat adat atau masyarakat tempatan yang bukan masyarakat adat. Hal ini disebabkan oleh, kearifan lokal adalah produk budaya yang memiliki nilai-nilai universal.

Oleh sebab itu dalam tulisan ini akan dikaji "Tinjauan Yuridis Filosofis

\footnotetext{
${ }^{9}$ Undang-Undang Republik Indonesia Nomor 32 Tahun 2009 Tentang Perlindungan Dan Pengelolaan Lingkungan Hidup.

${ }^{10}$ Undang Undang Republik Indonesia Nomor 11 Tahun 2020 Tentang Cipta Kerja.

${ }^{11}$ Peraturan Menteri Negara Lingkungan Hidup Nomor 10 Tahun 2010 Tentan Mekanisme Pencegahan Pencemaran Dan/Atau Kerusakan Lingkungan Hidup Yang Berkaitan Dengan Kebakaran Hutan Dan/Atau Lahan <www.hukumonline.com>.

${ }^{12}$ Peraturan Daerah Provinsi Kalimantan Tengah Nomor 1 Tahun 2020 Tentang Pengendalian Kebakaran Lahan.
} 
Eksistensi Kearifan Lokal”. Pembahasan tulisan ini dirumuskan dalam dua bagian, pertama bagaimana hubungan kearifan lokal dengan masyarakat adat? Kedua bagaimana hubungan penerapan kearifan lokal dengan masyarakat adat?

Kajian hubungan kearifan lokal dengan masyarakat adat diharapkan ditemukan, Pertama eksistensi kearifan lokal hanya produk dari masyarakat adat atau masyarakat lokal (tempatan) yang tidak hanya dikategorikan masyarakat adat. Kedua eksistensi kearifan lokal dalam penerapannya senantiasa bergantung dengan pembuatnya atau bisa mandiri (berdiri sendiri), sehingga setiap orang bisa menerapkan kearifan lokal.

\section{Metode}

Metode yang digunakan berupa penelitian yuridis normatif (Adrian Faridhi, 2017). Pendekatan filososfis yaitu menggunakan realitas sosial sebagai landasan berfikir untuk sampai kepada hakikat sesuatu. Adapun data yg digunakan adalah data skunder dengan bahan hukum primer berupa peraturan perundang-undangan dan bahan skunder berupa pendapat para ahli dibidangnya.

\section{Hasil dan Pembahasan}

\subsection{Eksistensi Kearifan Lokal}

Kearifan lokal terdiri dari dua kata, yaitu "kearifan (wisdom)" dan "lokal (local)". Pada Kamus Besar Bahasa Indonesia (KBBI), kearifan memiliki arti kebijaksanaan, sedangkan lokal diartikan sebagai setempat atau daerah setempat. ${ }^{13}$ Pada Kamus Inggris Indonesia (KII) John M. Echols dan Hassan Syadily, local berarti setempat, sedangkan wisdom (kearifan) sama dengan kebijaksanaan. ${ }^{14}$ Baik KBBI ataupun KII sama-sama

13 Unga Utari, I Nyoman Sudana Degeng, and Sa ' dun Akbar, 'Pembelajaran Tematik Berbasis

Kearifan Lokal Di Sekolah Dasar Dalam

Menghadapi Masyarakat Ekonomi Asean (MEA)

, , Jurnal Teori Dan Praksis Pembelajaran IPS,

1.1 (2016), $39-44$

<https://doi.org/10.17977/um022v1i12016p039>. mengartikan kearifan lokal sebagai "kebijaksanaan setempat". Artinya kearifan lokal berkaitan dengan kemampuan masyarakat tempatan dalam melahirkan sesuatu berdasarkan pengetahuan, sehingga sesuatu yang dilahirkan membawa kepada keselamatan bagi semesta alam.

Penggunaan istilah "lokal atau tempat" menunjukan bahwa hal ini tidak mengkhususkan bagi kelompok tertentu. Setiap kelompok masyarakat yang tinggal disuatu tempat bisa menghasilkan kebijaksanaan. Bisa disebut bahwa kebijaksanaan tidak bergantung dengan kelompok tertentu, karena kebijaksanaan adalah hasil dari kemampuan akal budi manusia. Jadi setiap manusia akan memiliki kemampuan untuk melahirkan kebijaksanaan.

Manusia adalah makhluk sosial yang memiliki wilayah tempat beristirahat, mendirikan tempat berlindung dan berusaha untuk memenuhi kebutuhan hidupnya. Manusia yang memiliki kecendrungan hidup bersosial menyebabkan manusia hidup berkelompok-kelompok dalam suatu wilayah. Pada akhirnya kehidupan kolektif manusia yang dikenal sebagai hewan rasional menyebabkan kelompok manusia menyadari pentingnya saling menjaga dengan melahirkan kebijakankebijakan yang bernilai baik. Kebijakan manusia yang berkelompok dan tinggal di wilayah tertentu tersebut melindungi alam semesta dari kerusakan, sehingga kebijakan tersebut dikenal dengan kearifan lokal.

Berdasarkan KII, Sartini mengartikan local wisdom (kearifan setempat) sebagai gagasan-gagasan setempat (local) yang bersifat bijaksana, penuh kearifan, bernilai

14 Sartini, 'Menggali Kearifan Lokal Nusantara Sebuah Kajian Filsafati' , Jurnal Filsafat, 37.2 (2004), 111 - 20

<https://jurnal.ugm.ac.id/wisdom/article/view/339 10/20262>. 
baik, yang tertanam dan diikuti oleh anggota masyarakatnya. ${ }^{15}$ Sartini tidak membatasi kearifan lokal diproduksi oleh masyarakat tertentu sesuai dengan penjelasannya mengatakan bahwa kearifan lokal adalah "gagasan-gagasan setempat". Sesuatu yang menjadi sesuatu sebagai kearifan lokal oleh Sartini lebih kepada kualitas gagasan setempat tersebut, seperti bersifat bijaksana, penuh kearifan, bernilai baik. Serta kualitas secara praksis kearifan lokal tersebut tertanam dan diikuti oleh anggota masyarakat setempat.

Sumarmi dan Amiruddin 16 mengartikan kearifan lokal sebagai pengetahuan lokal yang digunakan oleh masyarakat lokal untuk bertahan hidup dalam suatu lingkungannya yang menyatu dengan sistem kepercayaan, norma, hukum, budaya dan diekspresikan di dalam tradisi dan mitos yang dianut dalam jangka waktu yang cukup lama.

Ciri-ciri dan fungsi kearifan lokal menurut Sumarmi dan Amiruddin sebagai berikut:

a. Sebagai penanda identitas sebuah komunitas,

b. Sebagai elemen perekat kohesi sosial,

c. Sebagai unsur budaya yang tumbuh dari bawah, eksis dan berkembang dalam masyarakat, bukan merupakan sebuah unsur yang dipaksakan dari atas,

d. Berfungsi memberikan warna kebersamaan bagi komunitas tertentu,

e. Dapat mengubah pola pikir dan hubungan timbal balik individu dan kelompok dengan meletakkannya di atas common ground,

f. Mampu mendorong terbangunnya kebersamaan, apresiasi dan mekanisme bersama untuk

15 Sartini.

16 Utari, Degeng, and Akbar. mempertahankan diri dari kemungkinan terjadinya gangguan atau perusak solidaritas kelompok sebagai komunitas yang utuh dan terintegrasi.

Berdasarkan pemikiran di atas Sumarmi dan Amiruddin menyimpulkan kearifan sebagai identitas yang khas dan unik di suatu daerah atau tempat tertentu. Kearifan lokal juga menjadi sebuah kekuatan khusus dalam mempertahankan nilai-nilai yang terkandung di dalamnya. ${ }^{17}$

S. Swarsi Geriya menjelaskan secara konseptual, bahwa kebijaksanaan manusia yang bersandar kepada filososfi nilainilai, etika, cara-cara dan prilaku yang melembaga secara tradisional ada yang disebut dengan kearifan lokal dan ada yang disebut dengan keunggulan lokal. Terkait kearifan lokal, Geriya memahaminya sebagai nilai yang dianggap baik dan benar. Hal ini berakibat terhadap daya tahan dari nilai tersebut didalam kehidupan bermasyarakat hidup dalam waktu yang lama. Nilai tersebut juga bisa sampai kepada tahap melembaga.

Masyarakat tidak terpisahkan lagi dengan kearifan lokal yang lahir dari kebijaksanaan para leluhurnya. Kearifan lokal

a. Sebagai penanda identitas sebuah komunitas,

b. Sebagai elemen perekat kohesi sosial,

c. Sebagai unsur budaya yang tumbuh dari bawah, eksis dan berkembang dalam masyarakat, bukan merupakan sebuah unsur yang dipaksakan dari atas,

d. Berfungsi memberikan warna kebersamaan bagi komunitas tertentu,

e. Dapat mengubah pola pikir dan hubungan timbal balik individu dan 
kelompok dengan meletakkannya di atas common ground,

f. Mampu mendorong terbangunnya kebersamaan, apresiasi dan mekanisme bersama untuk mempertahankan diri dari kemungkinan terjadinya gangguan atau perusak solidaritas kelompok sebagai komunitas yang utuh dan terintegrasi.

Berdasarkan pemikiran di atas Sumarmi dan Amiruddin menyimpulkan kearifan sebagai identitas yang khas dan unik di suatu daerah atau tempat tertentu. Kearifan lokal juga menjadi sebuah kekuatan khusus dalam mempertahankan nilai-nilai yang terkandung di dalamnya. ${ }^{18}$

S. Swarsi Geriya menjelaskan secara konseptual, bahwa kebijaksanaan manusia yang bersandar kepada filososfi nilainilai, etika, cara-cara dan prilaku yang melembaga secara tradisional ada yang disebut dengan kearifan lokal dan ada yang disebut dengan keunggulan lokal. Terkait kearifan lokal, Geriya memahaminya sebagai nilai yang dianggap baik dan benar. Hal ini berakibat terhadap daya tahan dari nilai tersebut didalam kehidupan bermasyarakat hidup dalam waktu yang lama. Nilai tersebut juga bisa sampai kepada tahap melembaga.

Masyarakat tidak terpisahkan lagi dengan kearifan lokal yang lahir dari kebijaksanaan para leluhurnya. Kearifan lokal hidup terus menerus dari generasi ke generasi. Hal ini dikarenakan kearifan yang merupakan produk dari kebijaksanaan manusia yang disebut dalam bahasa agama Islam dengan "fitrah". 19

Ilmu antropologi mengenal istilah local genius selain dari istilah kearifan lokal. Quaritch Wales yang pertama kali memperkenalkan istilah Local genius.

18 Utari, Degeng, and Akbar.

19 Sartini.
Hhat Ayatrohaedi mengatakan bahwa para antropolog membahas secara panjang lebar pengertian local genius. Haryati Soebadio salah seorang yang membahas tentang local genius, mengatakan bahwa local genius adalah cultural identity, identitas/kepribadian budaya bangsa yang menyebabkan bangsa tersebut mampu menyerap dan mengolah kebudayaan asing sesuai watak dan kemampuan sendiri. ${ }^{20}$

Moendardjito juga membahas tentang local genius. Moendardjito berpendapat, bahwa unsur budaya daerah potensial sebagai local genius kerena telah teruji kemanpuannya untuk bertahan sampai sekarang. Ciri-cirinya adalah: ${ }^{21}$

a. Kemampuan bertahan terhadap budaya luar

b. Memiliki kemampuan mengakomodasi unsur-unsur budaya luar

c. Mempunyai kemampuan mengintegrasikan unsur budaya luar kedalam budaya asli

d. Mempunyai kemampuan mengendalikan

e. Mampu memberi arah pada perkembangan budaya

I Ketut Gobyah menjelaskan kearifan lokal (local genius) adalah kebenaran yang telah mentradisi atau ajeg dalam suatu daerah. Kearifan local atau local genius telah menyatu dengan kehidupan masyarakat setempat. Kearifan lokal juga diyakini oleh I Ketut memiliki korelasi dengan firman Tuhan. I Ketut mengatakan bahwa Kearifan lokal merupakan perpaduan antara nilai-nilai suci firman Tuhan dan berbagai nilai yang ada. Dari penjelasan I Ketut bisa dipahami bahwa kearifan lokal memiliki nilai-nilai transedensi dan hal tersebut menunjukkan bahwa masyarakat yang memiliki kearifan local tersebut sudah sampai kepada pradaban yang tinggi. 
Kearifan lokal yang merupakan kebenaran yang sudah mentradisi sekaligus memiliki nilai transedensi terbentuk sebagai keunggulan budaya masyarakat setempat maupun kondisi geografis dalam arti luas. Kebenaran yang sudah mentradisi menjadikan kearifan lokal merupakan produk budaya masa lalu yang patut secara terus-menerus dijadikan pegangan hidup. Kearifan yang dianggap bernilai lokal tetapi nilai yang terkandung didalamnya dianggap sangat universal. ${ }^{22}$ Kearifan lokal dikonsepsikan dengan berbagai nama seperti, pengetahuan setempat (local knowledge), kecerdasan setempat (local genius), dan kebijakan setempat (local wisdom). ${ }^{23}$

Ada beberapa pengertian kearifan dalam peraturan perundang undangan, sebagai berikut:

Pertama UU CK Pasal 18 terkait perubahan Undang-Undang Nomor 1 Tahun 20I4 tentang Perubahan atas Undang-Undang Nomor 27 Tahun 2007 tentang Pengelolaan Wilayah Pesisir dan Pulau-Pulau Kecil, Pasal 1 ayat (36) Kearifan Lokal adalah nilai-nilai luhur yang masih berlaku dalam tata kehidupan masyarakat ${ }^{24}$. Pengertian pertama mengkatogorikan kearifan lokal sebagai nilai luhur dan masih hidup dalam masyarakat. Nilai luhur ini tidak terikat oleh jenis suku tertentu, namun lebih kepada masyarakat yang ada pada daerah tersebut secara umum.

Kedua UU CK Pasal 22 terkait perubahan Undang-Undang Nomor 32 Tahun 2009 tentang Perlindungan dan Pengelolaan Lingkungan Hidup, Pasal 1 ayat (30). Kearifan lokal adalah nilai-nilai luhur yang berlaku dalam tata kehidupan masyarakat untuk antara lain melindungi

22 Sartini.

23 Hartuti Purnaweni Siswadi, Tukiman Taruna,

'LOKAL DALAM MELESTARIKAN MATA

AIR' , JURNAL ILMU LINGKUNGAN, 9.2

(2011), $63-68$

<https://doi.org/10.14710/ji1.9.2.63-68>.

24 Undang Undang Republik Indonesia Nomor

11 Tahun 2020 Tentang Cipta Kerja. dan mengelola lingkungan hidup secara lestari $^{25}$. Penjelasan Pasal 69 ayat (2), Kearifan lokal yang dimaksud dalam ketentuan ini adalah melakukan pembakaran lahan dengan luas maksimal 2 (dua) hektar per kepala keluarga untuk ditanami tanaman jenis varietas lokal dan dikelilingi oleh sekat bakar sebagai pencegahan penjalaran api ke wilayah sekelilingnya. $^{26}$

Pengertian kedua menambahkan penekanan terkait melindungi dan mengelola lingkungan hidup secara lestari. Pengertian kedua juga menekankan bahwa kearifan dalam kontek ini berkaitan erat dengan proses membuka lahan dengan cara membakar dalam bertani oleh masyarakat. Pada pengertian kedua ini juga tidak menekankan bahwa kearifan lokal adalah milik suku tertentu, namun dimiliki oleh masyarakat daerah tersebut.

Ketiga Peraturan Daerah Provinsi Kalimantan Tengah Nomor 1 Tahun 2020 Tentang Pengendalian Kebakaran Lahan, Pasal 1 ayat 21 Kearifan lokal adalah nilainilai budaya dan adat istiadat yang menjadi pedoman dalam interaksi antara individu atau kelompok, dengan sesama manusia serta hubungannya dengan alam dalam pengelolaan dan pemanfaatan sumber daya alam. ${ }^{27}$

Pengertian ketiga menjelaskan bahwa kearifan lokal tidak hanya berasal dari nilai-nilai adat istiadat namun juga budaya. Pada penjelasan tersebut nilai budaya dan nilai adat istiadat tidak bisa dipisahkan dalam membentuk kearifan lokal karena menggunakan kata "dan" sebagai penghubung. Pengertian ketiga juga menekankan bahwa kearifan lokal sebagai aturan dalam berinteraksi antara

\footnotetext{
25 Undang Undang Republik Indonesia Nomor

11 Tahun 2020 Tentang Cipta Kerja.

26 Undang Undang Republik Indonesia Nomor

11 Tahun 2020 Tentang Cipta Kerja.

27 Peraturan Daerah Provinsi Kalimantan

Tengah Nomor 1 Tahun 2020 Tentang

Pengendalian Kebakaran Lahan.
} 
individu, kelompok manusia dan juga dengan alam, karena manusia mengelola dan memanfaatkan alam.

$$
\text { Pengertian ketiga memiliki }
$$
perbedaan terkait asal dari kearifan lokal, karena produksi kearifan lokal berhubungan erat dengan adat istiadat. Hal ini menunjukkan bahwa peran masyarakat adat sangat menonjol pada kontek ini. Disisi lain nilai budaya juga memiliki andil, artinya ketika berbicara budaya maka bisa saja bukan masyarakat adat yang memproduksinya melainkan masyarakat yang tidak dikategorikan masyarakat adat juga bisa memproduksi budaya.

Adat kebiasaan diyakini pada dasarnya teruji secara alamiah dan niscaya bernilai baik, karena kebiasaan tersebut merupakan tindakan sosial yang berulangulang dan mengalami penguatan (reinforcement). Apabila suatu tindakan tidak dianggap baik oleh masyarakat, maka tindakan tersebut tidak akan mengalami penguatan secara terusmenerus. Pergerakan secara alamiah terjadi secara sukarela, karena dianggap baik atau mengandung kebaikan. Adat yang tidak baik hanya akan terjadi apabila dipaksakan oleh penguasa, maka adat yang dipaksakan tersebut tidak tumbuh secara alamiah. ${ }^{28}$ Adat yang diproduksi demikian akan mudah untuk ditemukan kesalahannya oleh akal, karena mengandung hal-hal yang buruk. Permasalahannya karena sudah menjadi adat, maka orang-orang yang lemah akalnya menganggapnya benar dan orangorang yang memiliki itikad buruk akan tetap mempertahankan hal tersebut.

Masyarakat adat menurut Alwasilah ada banyak. Masyarakat adat di Indonesia yang sampai saat ini masih memelihara kearifan lokalnya. Terbukti ampuh dalam menyelenggarakan pendidikan yang

28 Sartini.

29 Muhammad Priyatna, PENDIDIKAN

KARAKTER BERBASIS KEARIFAN LOKAL,

Edukasi Islami: Jurnal Pendidikan Islam, 25 disebut sebagai pendidikan tradisi, termasuk pendidikan budi pekerti atau karakter secara baik. Pada beberapa masyarakat-masyarakat adat memiliki karifan lokal yang bersumber dari nilai yang diinternalisasi secara kohesif yang artinya kearifan lokal tersebut telah menyatu dengan masyarakat adat. ${ }^{29}$

Kearifan lokal dapat didefinisikan sebagai kebijaksanaan atau nilai-nilai luhur yang terkandung dalam kekayaankekayaan budaya lokal. Jika melihat penjelasan Alwasih sebelumnya pada paragraf di atas bisa disimpulkan budaya lokal yang dmaksud berhubungan dengan masyarakat adat. Bentuknya bisa berupa tradisi, petatah-petitih, dan semboyan hidup. Kearifan lokal (local wisdom) dapat dipahami sebagai gagasan, nilainilai, pandangan-pandangan setempat (local) yang bersifat bijaksana, penuh kearifan, bernilai baik, yang tertanam dan diikuti oleh anggota masyarakatnya. ${ }^{30}$ Kearifan lokal yang bersifat bijaksana, penuh kearifan dan bernilai baik, maka seharusnya kearifan lokal bisa diterapkan secara universal karena nilai-nilai universal terkandung didalamnya.

Seperti yang ada di Desa Purwogondo. Bentuk-bentuk kearifan lokal juga bermacam-macam. Penduduk desa memiliki kearifan lokal berupa: pengetahuan, nilai-nilai, etika dan moral, dan norma-norma yang berupa anjuran, larangan, dan sanksi, serta ungkapanungkapan yang dipakai sebagai pedoman sikap dan perilaku masyarakat dalam memelihara, menjaga dan melestarikan mata air Tuk Serco. ${ }^{31}$

Untuk mempertahankan debit air mata air, penduduk desa memahami perlu pengelolaan hutan disekitar mata air dan daerah atasnya dengan kearifan lokal. Untuk memelihara dan mempertahankan kearifan lokal, masyarakat melakukan

October 2017, v <www.lfip.org> [accessed 7

May 2021].

30 Priyatna, V.

31 Siswadi, Tukiman Taruna. 
dengan memberikan pengertian dan saran kepada keluarga, tetangga, sanak-saudara dan anak-cucu tentang nilai-nilai, etika dan moral, serta norma-norma termasuk norma agama untuk dipakai sebagai pedoman bersikap dan berperilaku dalam menjalankan tradisi dan naluri menghargai alam Tuk Serco. ${ }^{32}$ Pada proses pemeliharaan dan mempertahankan kearifan lokal masyarakat melakukan transformasi pengetahuan kepada manusia lainnya. Hal ini menunjukkan kearifan lokal bisa diterapkan oleh siapapun dengan cara transformasi pengetahuan.

Nenek moyang bangsa Indonesia sebenarnya telah mewariskan beragam kearifan lokal yang dipakai sebagai pedoman sikap dan perilaku dalam berinteraksi dengan alam dan lingkungan. Fakta empiris kearifan lokal tersebut telah berhasil mencegah kerusakan fungsi lingkungan, baik tanah/lahan, hutan, maupun air. Contohnya seperti tradisi nyabuk gunung, susuk wangan, merti desa di Jawa Tengah, Subak di Bali, Sasi di Maluku, senguyun di Kalimantan, dsb. ${ }^{33}$

Pada budaya Jawa dikatakan sebagai budaya simbolis karena penuh dengan simbol. Sebagai contoh, tradisi wiwahan. Upacara perkawinan, didalamnya terdapat simbol-simbol wiwahan. Oleh sebab itu simbol-simbol wiwahan sangat berhubungan erat dengan masyarakat jawa. Suatu kehidupan yang mengungkapkan perilaku dan perasaan manusianya melalui berbagai upacara adat. Pada simbol-simbol yang digunakan sampai kini mengandung nilai-nilai budaya, etika, moral sangat penting dijelaskan kepada generasi selanjutnya. Ini adalah produk budaya dan begitu juga bahasa jawa itu sendiri. Hal ini merupakan kearifan local masyarakat jawa. ${ }^{34}$

32 Siswadi, Tukiman Taruna.

33 Siswadi, Tukiman Taruna.

34 Ni Wayan Sartini, 'Menggali Nilai Kearifan

Lokal Budaya Jawa Lewat Ungkapan (Bebasan,

Saloka, Dan Peribahasa)' , LOGAT: JURNAL

\subsection{Penerapan Kearifan Lokal}

Pasal 69 ayat (1) huruf h, Setiap orang dilarang melakukan pembukaan lahan dengan cara membakar. Ayat 2, Ketentuan sebagaimana dimaksud pada ayat (1) melakukan kegiatan dimaksud dengan huruf $h$ dikecualikan bagi masyarakat yang memperhatikan sungguh-sungguh kearifan lokal di daerah masing-masing. 35 Pada Pasal ini, penerapan kearifan lokal tidak hanya dibatasi pelaku adalah masyarakat. Daerah atau wilayah juga menjadi tolak ukur dibolehkanya penerapan kearifan lokal dalam membuka lahan dengan cara membakar.

Bisa dipahami bahwa, jika berada di daerah Rokan Hulu maka gunakanlah kearifan Rokan Hulu dalam melakukan pembukaan lahan dengan cara membakar. Jika berada di daerah Meranti, maka gunakanlah kearifan Meranti dalam membakar lahan. Selain itu pelaku penerapan kearifan lokal juga tidak bisa badan hukum seperti perusahaan pertanian atau perkebunan atau perusahaan yang bergerak dibidang lainnya. Hal ini disebabkan pelaku pelaksana kearifan lokal hanya masyarakat.

Pada penjelasan Pasal 69 ayat (2) lebih dijlaskan dengan detail terkait teknis penerapan kearifan lokal dalam kontek membuka lahan dengan cara mebakar. Jadi "daerah atau wilayah dan masyarakat" yang menjadi alat ukur kebolehan membuka lahan dengan cara membakar, tidak bisa diterjemahkan secara langsung boleh membakar menurut peraturan perundang-undangan.

Kriteria masyarakat yang diperbolehkan membuka lahan dengan cara membakar bukanlah diartikan dalam kelompok, namun dalam pengertian harus memenuhi kriteria sebagai berikut:

ILMIAH BAHASA DAN SASTRA, V.1 (2009), $28-37$.

35 Undang-Undang Republik Indonesia Nomor 32 Tahun 2009 Tentang Perlindungan Dan Pengelolaan Lingkungan Hidup. 
a. Luas lahan yang akan dibakar maksimal dengan luas 2 hektar;

b. Pelaku kegiatan membakar adalah 1 kepala keluarga;

c. Tanaman yang akan ditanami pada lahan yang akan dibakar adalah jenis varietas lokal;

d. Lahan yang akan dibakar terlebih dahulu dikelilingi sekat bakar dengan tujuan sebagai pencegahan terjadinya penjalaran api ke wilayah lain.

Kriteria ini bisa dibaca pada penjelasan Pasal 69 ayat (2), yang berbunyi "Kearifan lokal yang dimaksud dalam ketentuan ini adalah melakukan pembakaran lahan dengan luas maksimal 2 (dua) hektar per kepala keluarga untuk ditanami tanaman jenis varietas lokal dan dikelilingi oleh sekat bakar sebagai pencegahan penjalaran api ke wilayah sekelilingnya. ${ }^{36}$

Berbeda dengan Peraturan Menteri Lingkungan Hidup (Permen LHK) dalam membentuk aturan turunan dari Pasal 69 ayat (2). Bunyi Pasal yang begitu jelas dan disertai bunyi penjelasan Pasal yang sangat detail di terjemahkan berbeda oleh menteri lingkungan hidup. Lebih tepatnya peraturan menteri lingkungan hidup tidak mengakomodir kriteria masyarakat yang ada pada Pasal 69 ayat (2) sepenuhnya.

Peraturan Menteri Negara Lingkungan Hidup Nomor 10 Tahun 2010 Tentang Mekanisme Pencegahan Pencemaran Dan/Atau Kerusakan Lingkungan Hidup Yang Berkaitan Dengan Kebakaran Hutan Dan/Atau Lahan, Pasal 4 ayat (1) Masyarakat hukum adat yang melakukan pembakaran lahan dengan luas lahan maksimum 2 (dua) hektar per kepala keluarga untuk ditanami jenis varietas lokal wajib memberitahukan kepada kepala desa. ${ }^{37}$

36 Undang-Undang Republik Indonesia Nomor 32 Tahun 2009 Tentang Perlindungan Dan Pengelolaan Lingkungan Hidup.

37 Peraturan Menteri Negara Lingkungan Hidup Nomor 10 Tahun 2010 Tentan Mekanisme
Pada Pasal ini, kriteria masyarakat berubah menjadi masyarakat hukum adat (MHA). Tidak jelas dari mana asal penafsiran masyarakat menjadi masyarakat hukum adat. Norma yang disusun oleh menteri lingkungan hidup tentunya merugikan masyarakat pada umumnya, sebab tidak semua masyarakat bisa dikategorikan masyarakat adat. Padahal kearifan lokal adalah produk akal budi yang artinya manusia manapun tidak terkecuali selain masyarakat hukum adat bisa memproduksinya. Belum lagi kearifan lokal bisa senantiasa di transformasikan untuk dipertahankan dengan cara pendidikan atau transformasi pengetahuan.

Permasalahan baru hadir dengan kriteria masyarakat yang diatur oleh peraturan menteri. Masyarakat hukum adat secara administrasi membutuhkan pengakuan dari pemerintah. Masyarakat hukum adat yang belum mendapatkan pengakuan dari pemerintah melalui pemerintah daerah tetap dianggap tidak ada oleh sebagian penegak hukum. Hal buruknya, sebagian pemerintah daerah tidak melakukan dengan benar dan baik dalam mengakui masyarakat hukum adat yang ada di daerahnya bisa disebut tidak ada iktikat baiknya. Ini bisa dibuktikan proses pengakuan masyarakat adat Talang Mamak yang ada di kabupaten Indragiri Hulu.

Pada Pasal 5, tidak hanya masyarakat atau pelaku pembuka lahan yang lebih dipersempit pengaturannya, lahan yang bisa dibuka dengan cara membakarpun dipersempit. Lahan gambut menjadi lahan yang dilarang dalam membuka lahan dengan cara membakar. Padahal tidak semua lahan gambut pasti memiliki gambut yang dalam, ada gambut yang hanya setebal $10 \mathrm{~cm}$. sebagian masyarakat

Pencegahan Pencemaran Dan/Atau Kerusakan Lingkungan Hidup Yang Berkaitan Dengan Kebakaran Hutan Dan/Atau Lahan. 
lokal memiliki kearifan dalam membuka lahan dengan cara membakar di lahan gambut yang dangkal, namun peraturan menteri ini membatasinya.

Bunyi Pasal 5 ayat (1) Setiap orang dan/atau perusahaan dilarang melakukan kegiatan pembakaran lahan. Ayat (2) Kegiatan pembakaran lahan sebagaimana dimaksud pada ayat (1) dikecualikan untuk hal-hal yang bersifat khusus yang berada pada lahan bukan gambut. Ayat (3) Kegiatan pembakaran dilahan yang bersifat khusus pada lahan bukan gambut sebagaimana dimaksud pada ayat (2) dilakukan oleh petani peladang/pekebun yang berasal dari anggota Masyarakat Hukum Adat. ${ }^{38}$

Peraturan menteri ini menimbulkan tanda tanya bagi masyarakat yang bukan masyarakat hukum adat. Apakah masyarakat selain masyarakat hukum adat bisa membuka lahan dengan cara membakar, asalkan tetap sesuai dengan menggunakan kriteria Pasal 69 ayat (2) UU PPLH junto UU CK?

Permen LHK secara hirarki peraturan perundang-undanga tidak disebutkan tingkatan kedudukannya, namun tetap berlaku asalkan tidak bertentangan dengan aturan yang lebih tinggi. Pada kontek pertanyaan di atas, jawaban seharusnya "bisa", sebab Permen LHK tidak membatalkan UU PPLH junto UU CK. Hanya saja pengaturan terkait kebolehan masyarakat yang bukan MHA tidak diatur oleh Permen LHK. Tidak diaturnya tidak menyebakan terjadinya larangan bagi masyarakat yang bukan MHA membuka lahan dengan cara membakar, karena UU PPLH junto UU CK sudah membolehkan asalkan memenuhi kriteria yang sudah ditetapkan oleh UU.

\section{Kesimpulan}

a) Kearifan lokal tidak selalu diproduksi oleh masyarakat adat. Sebagian kearifan lokal bukanlah berasal dari masyarakat adat, tetapi masyarakat yang bukan dikategorikan masyarakat adat.

b) Penerapan kearifan lokal tidak bergantung dengan yang memproduksinya, karena kearifan lokal adalah nilai-nilai yang bersifat universal dan bisa di tranformasi atau diwarisi atau dipelajari oleh siapapun, sehingga penerapannya bisa dilakukan oleh siapapun.

\section{Daftar Pustaka}

Endar, R. (2020). AMPR Geruduk Mapolda Riau, Tuntut Keadilan Petani Rohul Iwan Kini Menjalani Sidang Kasus Pembakaran Lahan. Detikperistiwa.Com, p. https://www.detikperistiwa.com/n ews-183255/ampr-ge.

Faridhi, A. (2017). Penguji Peraturan Perundang-undangan Tunggal Keniscayaan. JURNAL MERCATORIA, 10(2), 180-196.

Peraturan Daerah Provinsi Kalimantan Tengah Nomor 1 Tahun 2020 Tentang Pengendalian Kebakaran Lahan.

Peraturan Menteri Negara Lingkungan Hidup Nomor 10 Tahun 2010 Tentan Mekanisme Pencegahan Pencemaran Dan/Atau Kerusakan Lingkungan Hidup Yang Berkaitan Dengan Kebakaran Hutan Dan/Atau Lahan <www.hukumonline.com>.

Priyatna, M. (2017). Pendidikan karakter berbasis kearifan lokal. Edukasi Islami: Jurnal Pendidikan Islam, 5(10).

Putra, E. P. (2020). Divonis Bersalah 6 Bulan, 15 Hari Terdakwa Irwan Pembakar Lahan Langsung Bebas. RiauPos.Co, 
p.Https://riaupos.jawapos.com/rok an-hulu/19/08/2020/

Sartini, N. W. (2009). Menggali nilai kearifan lokal budaya Jawa lewat ungkapan (Bebasan, saloka, dan paribasa). Jurnal ilmiah bahasa dan sastra, 1, 28-37.

Sartini, S. (2007). Menggali kearifan lokal Nusantara: Sebuah kajian filsafati. Jurnal filsafat, 14(2).

Siswadi, T. T., \& Purnaweni, H. (2011). Kearifan Lokal Dalam Melestarikan Mata Air. Jurnal Lingkungan Program Studi Ilmu Lingkungan, 9(2), 63-68.

Undang Undang Republik Indonesia Nomor 11 Tahun 2020 Tentang Cipta Kerja.
Undang-Undang Republik Indonesia Nomor 1 Tahun 2014 Tentang Perubahan Atas Undang Undang Nomor 27 Tahun 2007 Tentang Pengelolaan Wilayah Pesisir Dan Pulau-Pulau Kecil

Undang-Undang Republik Indonesia Nomor 32 Tahun 2009 Tentang Perlindungan Dan Pengelolaan Lingkungan Hidup.

Utari, U., \& Degeng, I. N. S. (2017). Pembelajaran tematik berbasis kearifan lokal di sekolah dasar dalam menghadapi Masyarakat Ekonomi Asean (MEA). Jurnal Teori dan Praksis Pembelajaran IPS, 1(1), 39-44. 